\title{
DNA 複製開始領域の特性
}

\author{
永田俊夫，大森治夫，村上洋太 \\ (京都大学ウイルス研究所)
}

真核生物の染色体は複製単位 DNA が多数連結した 形をとっていて，個々の単位からはいわゆるARS が単 離される. ARSは「自律複製能を持つDNA壇基配列」 で、複䋿が始まる定をった部位すなわら複製起点を含む ことが必須条件と考えられている，しかし研究の現状で は、これら ARS とその複製開始領域に関する知識はま た僅少である.

一方，ウイルス・稩菌・プラスミド等つゲノム DNA はふつら単一のレプリコンで, 複製開始領域の研究もは るかに進んでいる．ただし研究の進展に伴い，単一レプ リコンとはい觉鉒制鹳のィカニズムはけっして単純で はなく、高度に複雑であることがわかってきている、本 稿では，大腸菌細胞の中で複製する菌染色体およびプラ スミドのFと ColE1 について，最近われわれが得たデ 一タを中心袘製開始領域つ特性を考察しよう。

\section{1. 大腸菌染色体}

通常の複製は oriC から始まり，dnaA 遺伝子作用が 不可欠である(1)。すなら DnaA タンパク質の oriCへ の結合が必須条件だが，その結合部位は DnaA box コ ンセンサス配列 5'-TTAT ${ }_{\mathrm{A}}^{\mathrm{C}} \mathrm{CACA}-3^{\prime}$ で, oriC には4 （または5）個所これが存在する゙2)。この結合が二重らせ んの開裂などの構造変化を引き起こし, 複製開始に必要 なプライマー合成の鋳型として oriC を活性化すると 推湘されている. しかし分子量約 $52 \neq$ キダルトンの DnaA タンパ質について，その作用のメカニズムば た解明されていない。

ところで大腸菌の染色体は，oriCが機能を失ったい わば「危急」の状態では，oriC 以外の部位を副次的な複 製起点として利用する万法を心得ている. その方法の第

1 Properties of the DNA Region for Initiation of Replication.

Toshio NAGATA, Haruo OHMORl and Yota MU. RAKAMI (Institute for Virus Research, Kyoto University, Sakyo-ku, Kyoto 606)
一は、いわゆる integrative suppression である、溶原つ フージのゲノムやある種のプラスミド DNA は宿主染 色体に組名込まれると，通常子のレプリコンとしての機 能は抑觉られいかば腿った状態となる，艾れらのるるす のは，oriCが働かなくなったときにめざめて，自己本来 の複製能を回復するとともに，共有結合で連結された宿 主染色体の複製まで達成してしまうのである。

第二の方法は，大腸菌の $r n h$ 遗伝子の失活によって 実現される，その理由は索不明だが， $r m h$ 欠損条件下 では oriC とは全く別の他の部位が新しい複製起点とし

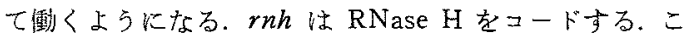
の醇素は，DNA-RNA ハイブリッド二本鎖の5ち RNA 鎖を分解するが，この酵素活性が失初れたときにの如， 副次的な新しい複製起点の「めざめ」が可能となる。こ れらの起点は ori $K$ と呼ばれ，大晹菌染色体の数個所に 散在すると報告されている(3)。そのタローニングによる 解析等の研究が進行中である.

\section{2. ミニFプラスミト}

大晹菌の雄性決定因子 F プラスミド $(94.5 \mathrm{~kb})$ を EcoRI で切った産物のうち, 約 $9 \mathrm{~kb} の \mathrm{f} 5$ 断片儿自律 複製能があり、ミニ Fプラスミドとして詳細な解析の詨 象となっている(4)。この断片のほほ中央部に複製臂始領 域力 ori-2 が市り，これと隣接の $\operatorname{rep} E$ 遗层子だけを持 つように切り縮めた pKV513 のようなプラスミドも作 られている(図 1$)^{(5)}$.

F因子は，前節で述べた integrative suppression を 行 ${ }^{(8)}$. たと光ば大腸菌の高温感受性 $d n a A 46$ 变異株 は，30 $\mathrm{C}$ では生育可能だが， $42^{\circ} \mathrm{C}$ では DNA 複製開始 が阻書され細胞增殖が停此与る。この株の染色体に五プ

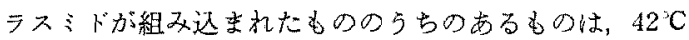
での生育能が回復する。これは，Fの複製起点から出発 して染色体全体の複製が可能となるためである。したが って, $\mathrm{F}$ は $d n a A$ 欠損条件下でも作動する，つまりdnaA 非依存性レプリコンと信しられてきた。 
$\mathbf{f 5}$

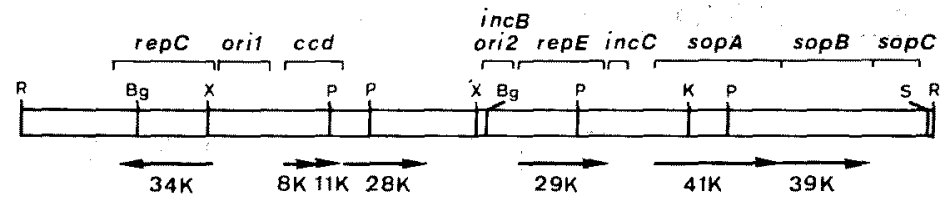

pSC138

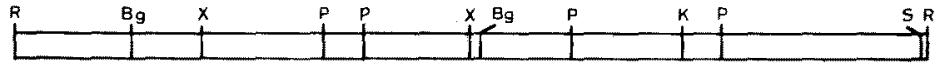

pKP1013

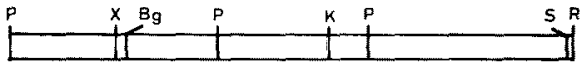

pKV 513

$(x)$

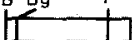

pZK58

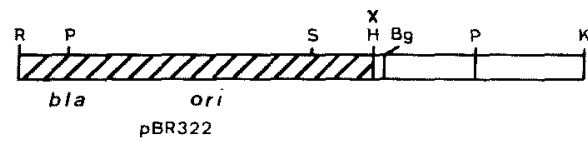

図 1 ミニFプラスミドの棈造 ${ }^{(5)}$

最上段心遍伝子，複慗起点，不和合性を支配する領域等を示す。矢印は䎐写の力向，乙 の下の数字は䕗伝子産物タンパ質の分子量表わす。制限醉素による切断部位も示して

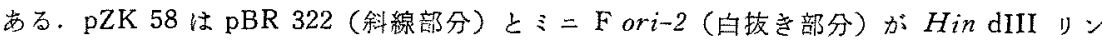
カ一で遮䋧されている。

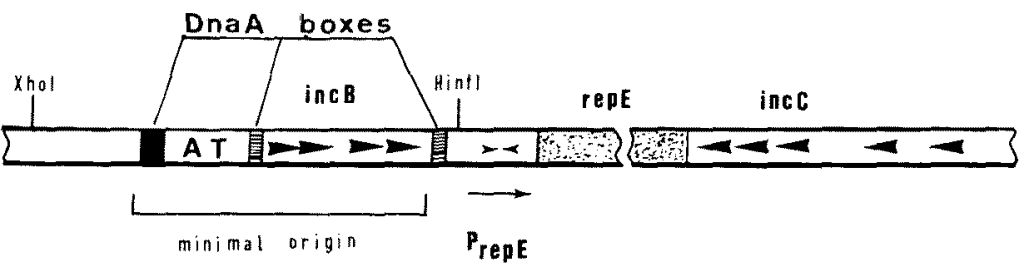

図 2 ミ = Fの ori-2 領域

ATはAT-rich 領域を，くさび形は反復配列の所在をそれ艺れ示す．矢印はrepE 造伝子プロモーターから転写される方向を示す. repE タンパク質 ( $29 \mathrm{~K})$ の反復配 列への特翼的結合が，複製拉よびュピー数の調節をつかさどると考方られている(4).

とこらが鼠近われわれは、ミニ Fプラスミド複製にと って, 大腸菌 $d n a A$ 遗伝子の作用が不可欠であることを

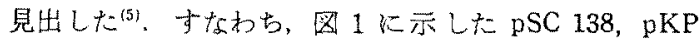
1013，拈よび pKV 513 の DNA を用い，そ礼ぞれが持 つ薬剂㓦性マーカー妾指標として，高温感受性の大晹菌 $d n a A$ 变翼株を形質転換させ上ら上すると， $30^{\circ} \mathrm{C}$ では可 能だが $42^{\circ} \mathrm{C}$ では不可能であった。用いた受容菌はdnaA 変異を持つが，rnh 変暴または溶原ファーシ P $2 \operatorname{sig} 5$ の共存により $42^{\circ} \mathrm{C}$ で生育できる、したがって，dnaA を必要としないブラスミド（たとえば pBR 322）情温 度て同程度の形窝転换体を生じる。また $d n a A^{+}$株では， $m h^{+}$です $m h^{-}$であいずれのプラスミドを用いても雨 温度で同等の形質転換が可能である。そこで、ミニ 用いて $30^{\circ} \mathrm{C}$ で得られた $\mathrm{n} a A$ 变異株の形質転換体，す
なわちブラスミド保持菌を $42^{\circ} \mathrm{C}$ 一移して解析した結 果, 細胞分裂の進行に伴って集団中に占めるブラスミド 保持菌の割合の急速な減少が見られた，つまり，dnaA 遗伝子作用が失活する $42^{\circ} \mathrm{C}$ では，ori-2 な起点とするミ ニ Fの複製が阻害される.

すでル決定されている ori-2 領域の塩基配列(7)を見る と, DnaA box コンセンサス配列に近いものが3カ所存 在する (図 2). とくに AT-rich 領域左端のものは1字 の不一致のみで 2 回重複の形となっている(図 3 ). る L ori-2 依存性の複製が真に dnaA 作用を不可欠とする ならば,DnaA タンパク質のこの DnaA box への結

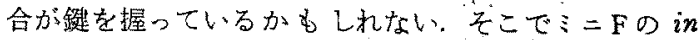
vitro の欠失変巽作成操作に上って図 3 に示与 DnaA box 久失变異プラスミドを得て，その複製開始の能力を 


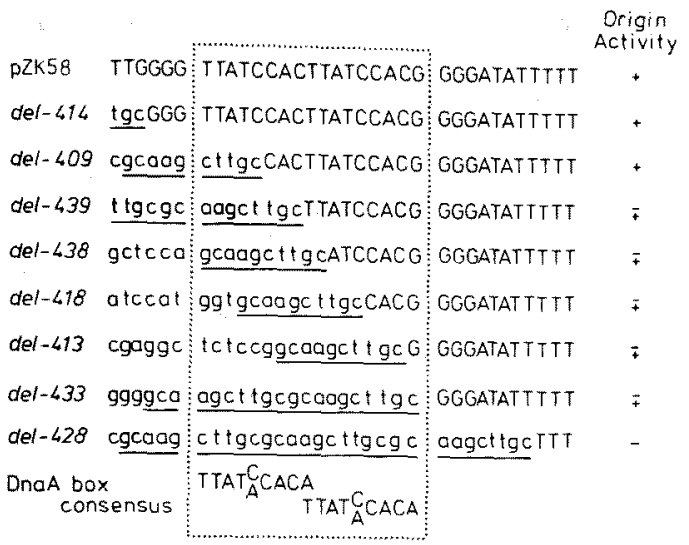

图 3 ミ = Fori-2 AT-rich 创域の左端に存在与 る2個のDnaA box 反復配列を欠失させた亲 異株の複製開始能を示才(5).

図1に示した pZK 58 の HindIII 切断部位より

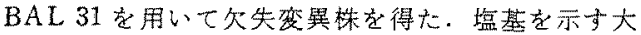
文字はF由来, 小文字は pBR 322 由来和よび Hin dIII ソンカー（下線つき）である。複製開始能の記 号十は正常の活性を育すること，一は活性の完全消 失，干は事実上の活性消失を学れぞれ示す。

調ベると，重複しているコンセンサス配列の少なくとも I個は不可久であることが見出された。

結論として， ori-2 を起点とするミ二Fの複製は， dnaA 遗伝子作用が必須であるといわ的ばならないが， ではFによる dnaA 变異株の integrative suppression はどのようにして可能となるかといら疑問が生じる。 れわれと前後して発表された他のグループによる同様の 実験結果 ${ }^{(8,9)}$ 総合して考光ると, DnaA タンパク質と oriC，ori-2 扩よび染色体隹組込交れて integrative suppression を行らときのFの複製起点との間のそれぞ れの相互作用儿微妙な相違があるか子しれない，他に必 考光られるいくつかの可能性があり，今㣪の解析に上っ て複䑾開始制衔の理解に近つけるであるう.

\section{ColE 1 タイプのプラスミド}

これら (ColE 1，pBR 322 等) は自己複製に必要なタ ンパク犋をコードする遗伝子を持たずすすへて宿主のる のに依存する。な招，複製開始領域か、約 80 境基八だ てて興型的な DnaA box 加l個存在するものの，これ は復製のため比必須ではない。

さて ColE 1 DNA は，複㹕開始領域 (ori) K $5^{\prime}$ $\mathrm{AAAAA}-3^{\prime}$ の配列学持つ。この右から2霍目のAを $+1 ， 3$ 番目を-1 と定めているが，こ机は一-555から 合成されてこの位㽡にまで及んボプライマーRNA 前慗

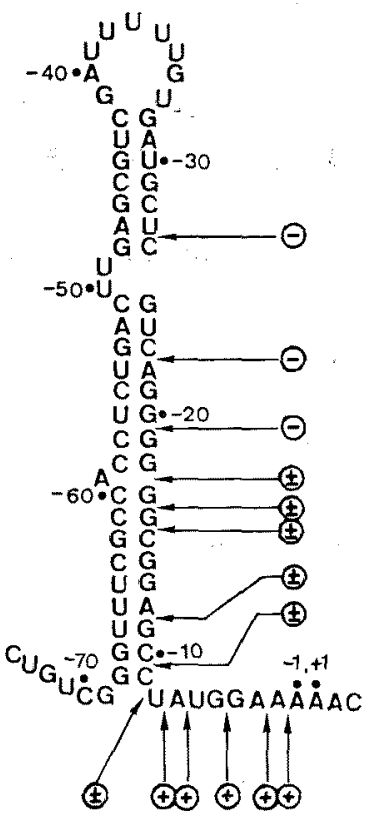

図 4 ColE1 プラスミドの ori 領域とその上流域 (+3より -74 まで) のプライマーRNA 前駆 体の推定二次榑造宗す。

+16より上流へ向けて欠失変異体を满築すると，

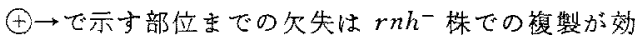
率よく起こること示す。小まで久失が進むとる の複裝效率の低下が起こる(低下の程度にはばらつ

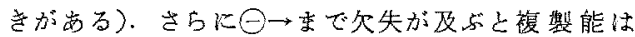
消失する。

体が，この位置で RNase Hによって切断され，生じた 3' OH 端老利用してここから DNA 伸長が始亲る起点だ からである(10,11)、したがって、いるゆる leading 鎖の複 製心は RNase H の閶与が不可久と思和れたが，この醉 素の活性を欠損した大腸菌 $r h$ 变異株を宿主として，

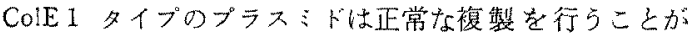
見出さ机た恼 14)

そこでわれわれは，ColE1タイプのプラスミドの ori 領域にいるいるな長さの欠失を持つ変孯株を模筑し，こ れらが $r n h^{+}$菌または $r n h^{-}$菌を宿主としたときに生じ る複製能の変化を解析した(15)，つ李り，ori 領域の構造 变化に刘底して，RNase $\mathrm{H}$ に依存する複製と依存しな

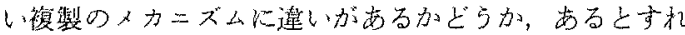
ばどのように違うか等の設問に答える手がかりを得よう と瓶みた就である。

Zの結果の大略を要約して図 4 に示した。佚は， ori 近修下流のヌクレオキド番号 + 16 から上流へ向けて種 
々の長さのものを得た. 欠失が +3 以前で終っているる

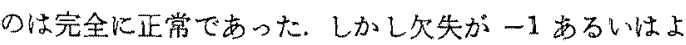
り上流にまで進み，5'-AAAAA-3' の配列が破壞された ものは $r h^{+}$菌を宿主として複製する能力を失ってしま った.ところがこれらのうち，欠失が -7 以前で終って いるものは，rnh-菌のなかでは効率よく複製すること ができたささらにー8あるいはそれ以上に進むと， $r h^{-}$ 菌に乱てても複製能が低下，さらには消失する結果とな った.

この領域では、プライマー RNA 前駆体が図 4 に示 したような二次構造を形成し，これが DNA-RNA 対 合を夷現するための必要条件であろうと推測されてい、 る(11,16). われわれの実験結果は以下の諸点を明らかにし た. RNase H 依存型は -3 から +2 までのAの反復構 造が不可欠であること， RNase $\mathrm{H}$ 非依存型の複製はこ の構造を必要とせず，しかも RNase $\mathrm{H} か ゙$ 動けば作動し ないこと，そして両型とも図 4 に示した二次構造の保持 が必須であり，上もにこの領域での DNA-RNA 対合形 成が必要亡想像される.

ColE 1 の RNase H 非依存㤠複製メカニズムそのもの の解明は今後の課題であるが，この型の複製は RNase H方失活したときにのみ作動する，すなわち RNase H 感受性である。この点において，さきに述べた大腸菌染 色体の oriK 上り出発する複製も同様であり，当し共通 のメカニズムが存在するならば，ColE1を対象とする解 析の進展が，細菌染色体の複製制御の解明につながるこ とが期待される。
(1) Y. Hirota, J. Mordoh and F. Jacob : J. Mol. Biol., 53, 369 (1970).

(2) R.S. Fuller, B.E. Funnell and A. Kornberg : Cell, 38, 889 (1984).

(3) B. de Massy, O. Fayet and T. Kogoma : J. Mol. Biol, 178, 227 (1984).

(4) B. C. Kline : Plasmid, 14, 1 (1985).

(5) Y. Murakami, H. Ohmori, T. Yura and T. Nagata: J. Bacteriol, 169, 1724 (1987).

(6) Y. Nishimura, L. Caro, C. M. Berg and Y. Hirota: J. Mol. Biol., 55, 441 (1971).

(7) T. Murotsu, H. Tsutsui and K. Matsubara : Mol. Gen. Genet., 196, 373 (1984).

(8) E. B. Hansen and M. B. Yarmolinsky : Proc. Natl. Acad. Sci. U.S. A., 83, 4423 (1986).

(9) B.C. Kline, T. Kogoma, J.E. Tam and M. S. Shields : J. Bacteriol., 168, 440 (1986).

(10) J. Tomizawa; H. Ohmori and R. E. Bird : Proc. Natl. Acad. Sci. U.S. A., 74, 1865 (1977).

（11）富沢純一：蛋白質 核酸 醉菜，31，1078(1986).

(12) T. Horiuchi, H. Maki and M. Sekiguchi : Mol. Gen. Genet., 195, 17 (1984).

(13) S. Naito, T. Kitani, T. Ogawa, T. Okazaki and H. Uchida: Proc. Natl. Acad. Sci. U.S. A., 81, 550 (1984).

(14) T. Kogoma: Proc. Natl. Acad. Sci. U.S. A., 81, 7845 (1984).

(15) H. Ohmori, Y. Murakami and T. Nagata: J. Mol. Biol., (in press).

(16) H. Masukata and J. Tomizawa : Cell, 44. 125 (1986). 